University of Nebraska - Lincoln

DigitalCommons@University of Nebraska - Lincoln

Publications from USDA-ARS / UNL Faculty

U.S. Department of Agriculture: Agricultural

Research Service, Lincoln, Nebraska

2000

\title{
Genetic Progress From 50 Years of Smooth Bromegrass Breeding
}

M. D. Casler

University of Wisconsin-Madison, michael.casler@ars.usda.gov

Kenneth P. Vogel

University of Nebraska-Lincoln, kvogel1@unl.edu

J. A. Balasko

West Virginia University

J. D. Berdahl

USDA-ARS

D. A. Miller

University of Illinois

See next page for additional authors

Follow this and additional works at: https://digitalcommons.unl.edu/usdaarsfacpub

Casler, M. D.; Vogel, Kenneth P.; Balasko, J. A.; Berdahl, J. D.; Miller, D. A.; Hansen, J. L.; and Fritz, J. O., "Genetic Progress From 50 Years of Smooth Bromegrass Breeding" (2000). Publications from USDA-ARS / UNL Faculty. 1916.

https://digitalcommons.unl.edu/usdaarsfacpub/1916

This Article is brought to you for free and open access by the U.S. Department of Agriculture: Agricultural Research Service, Lincoln, Nebraska at DigitalCommons@University of Nebraska - Lincoln. It has been accepted for inclusion in Publications from USDA-ARS / UNL Faculty by an authorized administrator of DigitalCommons@University of Nebraska - Lincoln. 


\section{Authors}

M. D. Casler, Kenneth P. Vogel, J. A. Balasko, J. D. Berdahl, D. A. Miller, J. L. Hansen, and J. O. Fritz 
Peterson, C.J., and W.H. Pfeiffer. 1989. International winter wheat evaluation: relationships among test sites based on cultivar performance. Crop Sci. 29:276-282.

Talbot, M. 1984. Yield variability of crop varieties in the UK. J. Agric. Sci. (Camb.) 102:315-321.
Troyer, A.F. 1996. Breeding widely adapted, popular maize hybrids. Euphytica 92:163-174.

Witcombe, J.R., A. Joshi, K.D. Joshi,, and B.R. Sthapit. 1996. Farmer participatory crop improvement. I. Varietal selection and breeding methods and their impact on biodiversity. Exp. Agric. 32:445-460.

\title{
Genetic Progress From 50 Years of Smooth Bromegrass Breeding
}

\author{
M. D. Casler,* K. P. Vogel, J. A. Balasko, J. D. Berdahl, D. A. Miller, J. L. Hansen, and J. O. Fritz
}

\begin{abstract}
Since its introduction from Eurasia, smooth bromegrass (Bromus inermis Leyss.) has become an important cool-season forage grass in North America. The objective of this study was to document breeding progress in smooth bromegrass between 1942 and 1995 in North America. Thirty cultivars or experimental populations were tested at up to seven sites in the eastern and central USA, with a range of soil types and climates. There have been small genetic changes in forage yield, brown leafspot resistance [caused by Pyrenophora bromi (Died) Drechs.], in vitro dry matter digestibility (IVDMD), and neutral detergent fiber (NDF) concentration. Brown leafspot resistance increased gradually, averaging 0.21 units decade $^{-1}$. Mean forage yield did not change for cultivars developed after 1942 , but was $0.54 \mathrm{Mg} \mathrm{ha}^{-1}(7.2 \%)$ higher for the post-1942 group than in 'Lincoln', a direct representative of smooth bromegrass introduced into North America. Selection for increased IVDMD led to an average increase in IVDMD of $9 \mathbf{g ~ k g}^{-1}$ (1.4\%), an increase in forage yield of $0.33 \mathrm{Mg} \mathrm{ha}^{-1}(5.0 \%)$, and a decrease in NDF of $-8 \mathrm{~g} \mathrm{~kg}^{-1}(-1.2 \%)$ in the post-1942 group. The slow rate of progress for smooth bromegrass forage yield is due to its complex polyploid inheritance, emphasis on traits other than forage yield, and relatively little concentrated attention from public and private breeders.
\end{abstract}

$\mathrm{S}$ MOOTH BROMEGRASS is native to Eastern Europe and broad expanses of temperate Asia. It was introduced into North America in 1884, but did not gain wide acceptance until the droughts of the 1930s. Smooth bromegrass was one of the few cool-season forage grasses to survive these droughts, leading to a huge demand and large seed shipments from the Great Plains to the eastern USA (Casler and Carlson, 1995). Several cultivars were released as direct increases of introduced ecotypes or as naturalized selections of these ecotypes. Large differences among seed lots in establishment capacity and forage production, discovered from experiment station tests, provided the basis for these initial "land race" cultivars.

M.D. Casler, Dep. of Agronomy, Univ. of Wisconsin-Madison, Madison, WI 53706-1597; K.P. Vogel, USDA/ARS, Dep. of Agronomy, Univ. of Nebraska, Lincoln, NE 68583; J.A. Balasko, Div. of Plant and Soil Sci., West Virginia Univ., Morgantown, WV 26506-6108; J.D. Berdahl, USDA/ARS, Northern Great Plains Res. Ctr., Mandan, ND 58544; D.A. Miller, Dep. of Crop Sci., Univ. of Illinois, Urbana, IL 61801; J.L. Hansen, Dep. of Plant Breeding and Biometry, Cornell Univ., Ithaca, NY 14853-1902; J.O. Fritz, Dep. of Agronomy, Kansas State Univ., Manhattan, KS 66506-5501. Joint contribution of the Illinois, Kansas, Nebraska, New York, West Virginia, and Wisconsin Agric. Exp. Stn., USDA/ARS, and the NE-144 Regional Research Committee, "Forage Crop Genetics and Breeding to Improve Yield and Quality." Received 21 Dec. 1998. *Corresponding author (mdcasler@facstaff.wisc.edu).

Published in Crop Sci. 40:13-22 (2000).
The first documentation of breeding smooth bromegrass was the single cycle of mass selection practiced by two Kansas farmers in the early 1900s to produce the cultivar Achenbach from "the tallest, best-filled, and lightest colored plants" (Vogel et al., 1996). Although there were sporadic breeding efforts at several experiment stations in the 1910s and 1920s, formal breeding did not begin in earnest until the late 1930s and early 1940s. This coincided with the widespread value and popularity of smooth bromegrass for revegetation of drought-damaged grasslands and marginal croplands throughout the Great Plains and midwestern regions.

The initial breeding efforts in smooth bromegrass improvement capitalized largely on existing natural variation among introduced germplasm sources that had become naturalized land races (Casler and Carlson, 1995). Many of the cultivars released in the 1940s consisted of increases from seed production fields that had consistently given rise to high-yielding forage production fields. Of these cultivars, Lincoln was the most widelygrown, presumably due to its superior performance in regional trials (Thomas et al., 1958). Fifty-five years later, Lincoln remains the most widely grown smooth bromegrass cultivar in the USA (Vogel et al., 1996). The commercialization of Lincoln and its contemporary cultivars is probably the greatest single-step genetic improvement made in smooth bromegrass breeding in the USA (Vogel et al., 1996).

Cultivated smooth bromegrass is an auto-allo-octoploid with $2 n=8 x=56$ chromosomes (Armstrong, 1991; Vogel et al., 1996). Its genomic formula is AAAAB $B_{1} B_{1} B_{2} B_{2}$, with an $A$ genome ancestor of $B$. erectus Huds. and unknown $\mathrm{B}$ genome ancestor(s). Both quadrivalents and bivalents are frequently formed during meiosis. However, complex species relationships within the genus suggest that autoploidy, alloploidy, interspecific hybridization, and genetic introgression between related populations have all contributed to the evolution of common octoploid smooth bromegrass (Armstrong, 1985). Limited inheritance studies suggest some genes possess tetrasomic inheritance (Dunn and Nasiruddin, 1971; Ghosh and Knowles, 1964). The high frequency of bivalent pairing in octoploids suggests the possible presence of genetic systems which suppress homeologous chromosome pairing (Armstrong, 1991). Thus, chromosome pairing relationships and genetic inheritance are far from resolved in smooth bromegrass, and may be variable among populations, among genotypes, and between the A and B genomes. Such complexity may allow the maintenance of large reserves of genetic variability within and among populations, 
favoring potential long-term breeding progress, but limiting genetic gains in short- and medium-term breeding programs.

Although numerous smooth bromegrass cultivars have been developed by intensive selection and breeding efforts since 1942, the amount of measurable progress achieved is perceived to be low. Initial results from breeding meadow (northern) climatypes in Canada achieved little relative to the common type (Knowles and White, 1949). Vogel et al. (1996) have estimated that $50 \mathrm{yr}$ of breeding have increased forage yield of smooth bromegrass by only 5 to $10 \%$. The dominance of Lincoln in today's seed market indirectly suggests that historical gains may have been insufficient to force its replacement. Conversely, estimated gains in forage yield of many other perennial forage species range from 3.3 to $4.9 \%$ decade $^{-1}$ (Veronesi, 1991). There is rapid cultivar turnover in most cool-season forage grasses, and forage producers are accustomed to occasionally adopting new and improved cultivars. Documentation of realized genetic gains and their potential impact on livestock agriculture is an important determinant of such adoption (Casler and Vogel, 1999).

The objectives of this experiment were to quantify genetic changes in agronomic performance of smooth bromegrass due to breeding efforts in North America between 1942 and 1995, and to determine phenotypic relationships among cultivars and breeding populations of smooth bromegrass. Because smooth bromegrass is grown over a wide range of environmental conditions and management schemes, we chose to measure phenotypes over the breadth of this environmental continuum, using "best recommended management" (BRM) at each location. This decision created several confounding factors among locations, because variation in local BRM was caused by variation in local environmental constraints, such as rainfall and temperature. We felt that this confounding was an acceptable consequence of using locally derived BRM.

\section{MATERIALS AND METHODS}

Thirty smooth bromegrass populations or cultivars were included in the experiment (Table 1). Selection of specific entries and the total number of entries was based strictly on availability of seed. Because of insufficient seed, some entries were not planted at all locations (Table 2). All cultivars were represented by certified seed.

The experiment was planted at seven locations using a randomized complete block design at each location (Table 2). There were three replicates at each location, except Hutchinson, KS, and Mead, NE, for which there were four replicates each. Plots were planted in spring 1991 at Illinois, Kansas, Nebraska, and Wisconsin, or in spring 1992 at the other locations. Plot size was: 0.9 by $3.0 \mathrm{~m}$ at Illinois, West Virginia, and Wisconsin; 1.5 by $4.0 \mathrm{~m}$ at New York; 1.5 by $4.6 \mathrm{~m}$ at Kansas and Nebraska; and 1.5 by $6.1 \mathrm{~m}$ at North Dakota. Seeding-year managment involved occasional clipping to control annual weeds and nitrogen fertilization to stimulate seedling growth. Nitrogen fertilization during harvest years is described in Table 2. Fertilization with $\mathrm{P}$ and $\mathrm{K}$ was done according to soil test results. Variation in management among locations was due to use of locally derived BRM. This is a widely accepted practice for measuring crop yield gains due to breeding (Fehr, 1984; Veronesi, 1991) and ensures that estimates of genetic gains are realistic and have a broad infer-

Table 1. List of smooth bromegrass entries included in the regional test, including some origin, pedigree, and selection history information.

\begin{tabular}{|c|c|c|c|c|c|c|}
\hline Entry & $n \dagger$ & Yeart & Climatype§ & Origin & Pedigree & IVDMDI \\
\hline WB88S-Tu & 3 & NA & $\mathbf{M}$ & Russia & PI 538863 & No \\
\hline WB88S-Ch & 4 & NA & $\mathbf{M}$ & Russia & PI 538862 & No \\
\hline WB88S-Yu & 2 & NA & $\mathbf{M}$ & Russia & PI 538865 & No \\
\hline WB88S-Ka & 3 & NA & M & Russia & PI 538859 & No \\
\hline Lincoln & 5 & 1942 & $\mathbf{S}$ & Nebraska & Hungary & No \\
\hline Lancaster & 5 & 1950 & $\mathbf{S}$ & Nebraska & unknown & No \\
\hline Manchar & 6 & 1943 & I & Washington & Manchuria & No \\
\hline Carlton & 5 & 1961 & M & Saskatchewan & common & No \\
\hline Magna & 5 & 1968 & I & Saskatchewan & Fischer & No \\
\hline Lyon & 7 & 1950 & $\mathbf{S}$ & Nebraska & Lincoln & No \\
\hline Barton & 7 & 1975 & $\mathbf{S}$ & Iowa & diverse & No \\
\hline Beacon & 5 & 1973 & $\mathbf{S}$ & Iowa & diverse & No \\
\hline Saratoga & 7 & 1955 & $\mathbf{S}$ & New York & diverse & No \\
\hline Sac & 7 & 1962 & $\mathbf{S}$ & Wisconsin & diverse & No \\
\hline Rebound & 6 & 1978 & $\mathbf{S}$ & South Dakota & Saratoga & No \\
\hline York & 7 & 1989 & $\mathbf{S}$ & New York & Saratoga & No \\
\hline Radisson & 6 & 1989 & $\mathbf{S}$ & Saskatchewan & Magna & No \\
\hline Signal & 5 & 1983 & $\mathbf{I}$ & Saskatchewan & Magna & No \\
\hline Alpha & 6 & 1995 & $\mathbf{S}$ & Wisconsin & WB8 & Yes \\
\hline Badger & 7 & 1990 & $\mathbf{S}$ & Wisconsin & WB8 & Yes \\
\hline Lincoln-HDMD-C3 & 7 & 1990 & $\mathbf{S}$ & Nebraska & Lincoln & Yes \\
\hline Lincoln-HDMDYD-C3 & 7 & 1990 & $\mathbf{S}$ & Nebraska & Lincoln & Yes \\
\hline NE BI 1 & 7 & 1990 & $\mathbf{S}$ & Nebraska & diverse & Yes \\
\hline NE BI 2 & 6 & 1990 & $\mathbf{S}$ & Nebraska & diverse & Yes \\
\hline PL-BDR1 & 6 & 1986 & $\mathbf{S}$ & Pennsylvania & diverse & No \\
\hline WB19e & 6 & 1987 & $\mathbf{S}$ & Wisconsin & NE, WI & Yes \\
\hline WB20e & 4 & 1987 & $\mathbf{S}$ & Wisconsin & NE, WI & Yes \\
\hline WB10-hDS & 3 & 1984 & $\mathbf{S}$ & Wisconsin & WB8 & Yes \\
\hline WB10-hD & 3 & 1984 & $\mathbf{S}$ & Wisconsin & WB8 & Yes \\
\hline WB10-IN & 4 & 1984 & $\mathbf{S}$ & Wisconsin & WB8 & Yes \\
\hline
\end{tabular}

$\dagger$ Number of locations.

+ Year of release for cultivar or synthesis for experimental population. $\mathrm{NA}=$ not applicable.

$\S \mathbf{M}=$ meadow (northern), $\mathbf{S}=$ steppe (southern), $\mathbf{I}=$ intermediate.

II Presence or absence of selection pressure for in vitro dry matter digestibility (IVDMD). 
ence range. Inferences derived from a specific location were recognized as specific to the BRM used at that location.

Data were collected beginning the year after seeding for all locations, except Nebraska and Wisconsin, for which stands were allowed to thicken for one additional year prior to data collection. Prior to first harvest, two plant height measurements were made: height to the top of the highest panicle and canopy height. Maturity of each plot was scored using the Nebraska rating scale (Moore et al., 1991). Forage yield of the entire plot at Illinois, West Virginia, and Wisconsin, or a 0.9-m swath at Kansas, Nebraska, New York, and North Dakota was measured following cutting with a flail chopper or sickle-bar mower. Cutting height was $9 \mathrm{~cm}$ at each location, except West Virginia $(7 \mathrm{~cm})$. A 300 - to 500-g dry matter sample was taken on each plot for dry matter determination. The number of cuts per location was determined principally by moisture availability and timing of the first cut (Table 2). Ground cover of smooth bromegrass was rated on a scale of 0 to 100 immediately after first cut of the last production year for each location. Reaction to brown leafspot was scored just prior to first cut in each year at Wisconsin by means of a scale of $0=$ no symptoms to $10=$ leaves completely diseased.

Dry matter samples from all first-cut harvests were dried at $60^{\circ} \mathrm{C}$ and ground through a 1-mm screen of a Wiley-type mill and again through a $1-\mathrm{mm}$ screen of a cyclone mill. Ground samples were sent to the USDA-ARS Forage Research Laboratory at Lincoln, NE, for forage quality analysis. Sample NIRS spectra were collected from all dried and ground samples with a Model 6500 scanning monochromator (NIRSystems, Silver Spring, MD). Sample spectra were categorized into three groups by the "center" option of ISI software (ISI Infrasoft International, NIRSystems, Silver Spring, MD). Samples were then selected from each group by the "select" option of the ISI software. The spectra from these samples were then merged into one file of 287 sample scans. The scan file was used to select 255 samples that were analyzed in triplicate for in vitro dry matter digestibility (IVDMD) and neutral detergent fiber (NDF). The scan file also was used to select 100 samples for determination of forage nitrogen $(\mathrm{N})$ concentration from the subset of 255 samples.

Sample N determinations were completed by the University of Nebraska Agronomy Department Soil and Plant Analytical Laboratory by using the LECO combustion method (Model FP 428, LECO Corporation, St. Joseph, MI) (Bremmer, 1996; Watson and Issac, 1990). The ANKOM Rumen Fermenter and the ANKOM Fiber Analyzer (ANKOM Technology Cor- poration, Fairport, NY) were used in the IVDMD and NDF analyses, respectively, by procedures described by Vogel et al. (1999).

For the IVDMD procedure, rumen fluid was a 50/50 mix of fluid from a steer on a high quality alfalfa (Medicago sativa L.) diet and from a steer on a low quality diet that consisted primarily of ground corn (Zea mays L.) cobs. The Kansas State buffer was used in the first digestion step followed by direct acidification (Vogel et al., 1999). ANKOM F57 filter bags containing $0.5 \mathrm{~g}$ of dried sample were used for the IVDMD and sequential fiber analyses. Eight fermentation vessels were used in each IVDMD replicate so that all samples could be analyzed with the same batch of rumen fluid.

Laboratory mean values were used to develop calibration and prediction equations by modified partial least squares with ISI software. Concentration of N, NDF, and IVDMD of all samples from all locations were then predicted by the NIRS prediction equations. The predicted NIRS values were used in the statistical analyses. Calibration statistics for N, NDF, and IVDMD, respectively, were as follows: $\mathrm{SEC}=0.55,6.90$, $8.54 \mathrm{~g} \mathrm{~kg}^{-1} ; R^{2}=0.99,0.95$, and 0.97 . Prediction statistics for $\mathrm{N}, \mathrm{NDF}$, and IVDMD, respectively, were as follows: SEP = $1.0,14.9$, and $21.4 \mathrm{~g} \mathrm{~kg}^{-1}$; slope $=1.06,0.97,1.10 ; r^{2}=0.98$, 0.82 , and 0.87 .

All data were analyzed by location, because imbalance in the number of entries per location was too extreme to allow analyses across locations. Total annual forage yield was analyzed separately for each year and as plot means over years by conventional analysis of variance and nearest neighbor analysis, NNA (Brownie et al., 1993), separately for each location. Least squares means from NNA were used to generate mean squares for the adjusted main effect of entry and the entry $\times$ year interaction. The efficiency of NNA relative to conventional ANOVA was computed as described by Brownie et al. (1993). Other variables were analyzed by conventional randomized complete block or split-plot-in-time models (Steel et al., 1996). Years and entries were assumed to have fixed effects, while replicates were assumed to have random effects.

Because genotype $\times$ location interactions could not be tested by ANOVA, the relative magnitude of genotype $\times$ location interactions was characterized by computing rank correlation coefficients among locations. Patterns of rank correlation coefficients were studied with respect to geographic location, $\mathrm{N}$ fertilization rate, and harvest frequency (Table 2) to determine if any interactions could be attributed to any of these factors. Contrasts were used to test specific differences

Table 2. Locations used in the regional smooth bromegrass test, including soil type, latitude and longitude, harvest frequency, and nitrogen fertilization.

\begin{tabular}{|c|c|c|c|c|c|c|}
\hline Location & $n \dagger$ & Soil type & $\begin{array}{l}\text { Latitude- } \\
\text { longitude }\end{array}$ & $h_{\dagger}^{\dagger}$ & $\mathbf{y r} \dagger$ & $\begin{array}{l}\mathrm{N} \text { fertilization } \\
\text { rate and timing }\end{array}$ \\
\hline Urbana IL & 23 & $\begin{array}{l}\text { Drummer silty clay loam (fine-silty, mixed, mesic } \\
\text { Typic Haplaquoll) }\end{array}$ & $\begin{array}{l}40^{\circ} 7^{\prime} \mathbf{N} \\
88^{\circ} 14^{\prime} \mathrm{W}\end{array}$ & 1 & 3 & $112 \mathrm{~kg} \mathrm{~N} \mathrm{ha}^{-1}$ in early spring \\
\hline Hutchinson, KS & 19 & $\begin{array}{l}\text { Clark loam (fine-loamy, mixed, thermic Typic } \\
\text { Calciustoll) and Ost clay loam (fine-loamy, } \\
\text { mixed, thermic Typic Argiustoll) complex }\end{array}$ & $\begin{array}{l}38^{\circ} 1^{\prime} \mathbf{N} \\
\quad 97^{\circ} 55^{\prime} \mathbf{W}\end{array}$ & 1 & 2 & $112 \mathrm{~kg} \mathrm{~N} \mathrm{ha}^{-1}$ in early spring \\
\hline Mead, NE & 27 & $\begin{array}{l}\text { Sharpsburg silt loam (fine, montmorillonitic, mesic } \\
\text { Typic Argiudoll) }\end{array}$ & $\begin{array}{l}41^{\circ} 13^{\prime} \mathbf{N} \\
9^{\circ} 29^{\prime} \mathrm{W}\end{array}$ & 2 & 3 & $100 \mathrm{~kg} \mathrm{~N} \mathrm{ha}^{-1}$ in early spring \\
\hline Ithaca, NY & 15 & $\begin{array}{l}\text { Rhinebeck silt loam (fine, illitic, mesic Aeric } \\
\text { Ochraqualf) }\end{array}$ & $\begin{array}{l}42^{\circ} 27^{\prime} \mathbf{N} \\
7^{\circ} 31^{\prime} W\end{array}$ & 2 & 2 & $\begin{array}{l}56 \mathrm{~kg} \mathrm{~N} \mathrm{ha-1} \text { in early spring and } \\
\text { after the first two harvests }\end{array}$ \\
\hline Mandan, ND & 30 & $\begin{array}{l}\text { Parshall fine sandy loam (coarse-loamy, mixed } \\
\text { Pachic Haploboroll) }\end{array}$ & $\begin{array}{l}46^{\circ} 48^{\prime} \mathbf{N} \\
100^{\circ} 52^{\prime} W\end{array}$ & 1 & 3 & $\begin{array}{l}45 \mathrm{~kg} \mathrm{~N} \mathrm{ha}^{-1} \text { in October prior to } \\
\text { each harvest year }\end{array}$ \\
\hline Morgantown, WV & 15 & $\begin{array}{l}\text { Dormont silt loam (fine-loamy, mixed Ultic } \\
\text { Hapludalf) }\end{array}$ & $\begin{array}{l}39^{\circ} 39^{\prime} \mathbf{N} \\
7^{\circ} 56^{\prime} \mathrm{W}\end{array}$ & 3 & 3 & $\begin{array}{l}60 \mathrm{~kg} \mathrm{~N} \mathrm{ha} \mathrm{Na}^{-1} \text { in early spring and } \\
\text { after the first two harvests }\end{array}$ \\
\hline Arlington, WI & 30 & $\begin{array}{l}\text { Plano silt loam (fine-silty, mixed, mesic Typic } \\
\text { Argiudoll) }\end{array}$ & $\begin{array}{l}4^{\circ} 20^{\prime} \mathbf{N} \\
8^{\circ} 23^{\prime} \mathbf{W}\end{array}$ & 3 & 3 & $\begin{array}{l}80 \mathrm{~kg} \mathrm{~N} \mathrm{ha-1} \text { in early spring and } \\
\text { after the first two harvests }\end{array}$ \\
\hline
\end{tabular}

$\dagger n=$ number of entries, $h=$ number of harvests per year, and $\mathrm{yr}=$ number of years harvested. 
among entries related to introduction and selection. Contrasts were estimated and tested by conventional approaches within each location. Main effect contrasts among entries (averaged across locations) were estimated by averaging estimated contrast effects across locations and testing with paired $t$-tests (either one- or two-tailed, depending on expectations). Significance of these t-tests indicated a consistently positive or negative contrast effect across locations. Linear responses of measured variables to year of cultivar release were computed by linear regression analysis. To identify individual entries with superior average performance across locations, each entry was ranked on the basis of its mean value within a location. Mean ranks across locations were computed to identify the most consistently high-ranking entries. In the case of NDF, for which low values are desirable, entries were ranked in ascending order.

Entries were grouped by cluster analysis applied to a balanced subset of the data. For three locations (Nebraska, North Dakota, and Wisconsin), a subset of 27 entries was present at each location. Means of these 27 entries, across the three locations, were standardized and used in a cluster analysis based on Ward's method of minimizing the pooled withincluster sum of squares at each step (Milligan, 1980). Nine variables were used to form the cluster analysis: Cut 1 forage yield, regrowth forage yield, maturity, panicle height, brown leafspot reaction, ground cover, IVDMD, NDF, and N concentration. All nine variables demonstrated significant differences among entries in a combined analysis of variance across the three locations.

\section{RESULTS AND DISCUSSION Maturity}

Average maturity stages of first harvest were as follows: Illinois-late jointing (mean of 2.7); Nebraska, New York, West Virginia, and Wisconsin-between head emergence and anthesis (mean of 3.1-3.7); North Dakota-initial seed ripening (mean of 4.0); and Kansas-dough stage (mean of 4.4). The ranges among entry means within locations were extremely small, allowing detection of significant differences for maturity at only three locations: Kansas, New York, and Wisconsin. Entry $\times$ year interactions were not significant.

Averaged across years, the range from earliest to latest maturing entry at the time of first harvest was late boot to partial panicle emergence (all spikelets, but not the full peduncle) at Wisconsin; partial panicle emergence to pre-anthesis at New York; and early soft dough to late hard dough stage at Kansas. The PL-BDR1 population always ranked as the latest maturing entry and 'York' always ranked as the earliest maturing entry. 'Carlton' and 'Magna' a meadow and an intermediate climatype, respectively, were almost as late maturing as PL-BDR1 at the three locations, although this trend was not observed for the other meadow and intermediate climatype germplasms. There were numerous entries for which rankings were highly inconsistent among the three locations, suggesting the existence of genotype $\times$ location interaction effects for some entries.

These results indicate that genetic variation does exist for the timing of reproductive maturity in smooth bromegrass, despite numerous reports to the contrary (see reviews: Buxton and Casler, 1993; Casler and Vo- gel, 1999). Statistical significance, while not observed at every location in this study, was likely a result of adequate replication within experiments and across years and appeared to be independent of latitude and timing of first harvest. The range among entries was extremely small compared with that commonly observed in other temperate forage grasses (Barnes et al., 1995), and may be of little practical significance. The maximum range among entries was little more than 3 to $5 \mathrm{~d}$ to reach a given maturity stage and may have little effect on optimal management of a cultivar. Nevertheless, the existence of genotypic variation for maturity suggests that it may be possible to develop transgressive segregants for earliness or lateness. The extreme photoperiod sensitivity of smooth bromegrass limits its adaptation to mixtures with alfalfa because of its sensitivity to cutting between jointing and anthesis (Vogel et al., 1996). Development of extremely early or late populations might improve the adaptation of smooth bromegrass to mixtures with alfalfa.

\section{Ground Cover}

Entries differed significantly $(P<0.01)$ for mean ground cover during the last harvest year at all locations, except Illinois and New York. Because seeding rates for each entry were computed on a pure live seed basis and all plots established well, variation in ground cover values represented differential responses of entries to local stress factors that cause stand losses. The range among entry means varied among locations with North Dakota and Nebraska showing small ranges (7 and 13 percentage units, with overall means of 98 and $92 \%$, and LSD[0.05] values of 3 and $8 \%$, respectively) and Kansas, West Virginia, and Wisconsin showing large ranges (25-38 percentage units, with overall means of $74-78 \%$, and LSD [0.05] values of 11-22\%). Although the harsher environments (low mean ground cover) were not related to latitude or harvest frequency, they tended to cause greater separation among entries.

There appeared to be relatively large genotype $x$ location interactions for ground cover, with most entries showing dramatic changes in ranking among locations. This suggested that there may be some large differences in adaptation range among these entries. For example, ground cover of 'Beacon' and 'Barton' at Wisconsin was below average (60 and $65 \%$, respectively), but was average to above-average at all other locations. 'Signal' and 'Badger' had low ground cover at Kansas (68\%), but average to above-average ground cover at all other locations. The PL-BDR1, Lincoln-HDMD-C3, and Lincoln-HDMDYD-C3 populations had below-average ground cover at West Virginia and Wisconsin and average to above-average ground cover at all other locations. Nine entries ('Alpha', 'Radisson', 'Rebound', 'Saratoga', WB19e, WB20e, and the three WB10 populations) had above-average ground cover at all locations.

Few contrasts among entries were significant for ground cover. The exception was the effect of selection for IVDMD in the Nebraska and Wisconsin programs. When measured at Kansas, Nebraska, and North Da- 
kota, entries selected for increased IVDMD had mean ground cover that was 6 to 9 percentage units (6.4$11.8 \%$ of the mean) higher than entries that had not been selected for IVDMD (all with $P<0.05$ ). A dramatic loss in persistence, such as that observed following Cycle 3 selection for increased IVDMD in switchgrass, Panicum virgatum L. (Buxton et al., 1995), was not observed in smooth bromegrass.

\section{Plant Height}

There were significant differences among entries for both panicle and canopy height at all seven locations. Because panicle and canopy height were highly correlated with each other $(r=0.61$ to 0.94 ; all $P<0.01)$, only panicle height will be discussed. The range among entry means was as low as $12 \mathrm{~cm}$ at West Virginia and as high as $27 \mathrm{~cm}$ at North Dakota, with LSD(0.05) values ranging from 7 to $15 \mathrm{~cm}$. Badger, Lincoln, and York were the only entries that were consistently taller than average at all or most locations. Carlton and the four WB88S populations, the five meadow climatypes, were the only entries that tended to be shorter than average at most locations. All other entries were highly sensitive to entry $\times$ location interactions, with large changes in ranking among locations.

There were generally no significant contrast effects for panicle or canopy height. The only exception to this was for York, which was significantly taller than its parent cultivar Saratoga at five of seven locations. Increases in plant height of York compared with Saratoga ranged from 7 to $12 \mathrm{~cm}(6.9-14.6 \%)$ at these five locations.

\section{Brown Leafspot Reaction}

Entry means were significantly different for brown leafspot reaction $(P<0.01)$, ranging from 1.2 to 5.0 with a mean of 3.7. There was a significant entry $\times$ year interaction, but relatively high rank correlation coefficients among years $(r=0.61-0.71 ; P<0.01)$ indicated relatively minor changes in rank among the $3 \mathrm{yr}$ of evaluation at Wisconsin.

Brown leafspot reaction declined by an average of 0.21 units decade $^{-1}$ (Fig. 1). Some of this response can be attributed to the extremely high brown leafspot resistance of PL-BDR1, which is the product of four cycles of recurrent selection for resistance (Berg et al., 1986). However, there were several other entries with superior brown leafspot resistance, most deriving from the Wisconsin program, but including York from New York, and Barton from Iowa. These entries were developed largely by selection among field-grown spaced plants and reflect the frequent presence of large amounts of natural inoculum of $P$. bromi. Elimination of the most susceptible genotypes prior to applying selection pressure for forage nutritive value traits has been the common procedure in the Wisconsin program (Ehlke et al., 1986). This is the first documentation of superior brown leafspot resistance in the Wisconsin germplasm, for which entry means ranged from 2.3 to 4.0 with a mean of 3.0. In addition, York was significantly better than

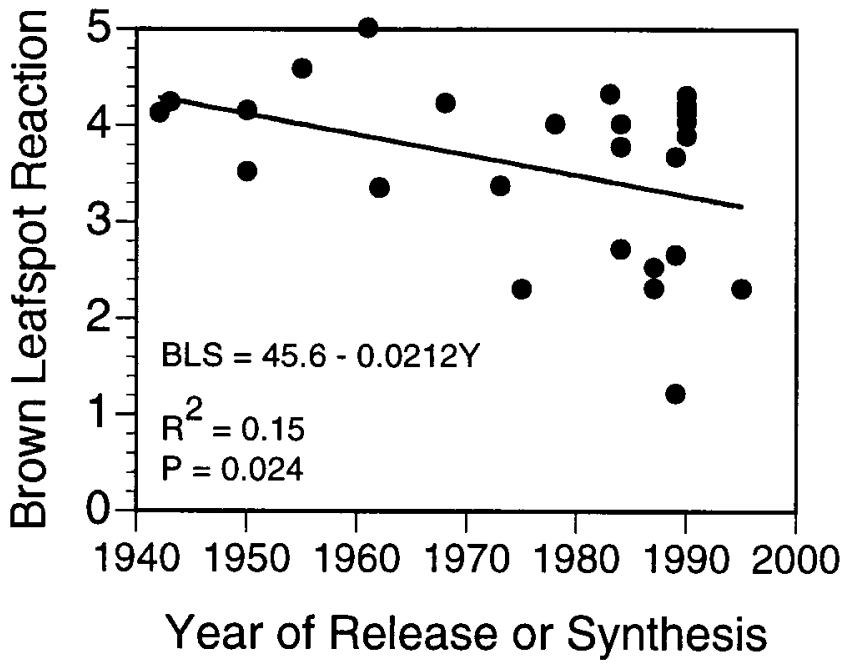

Fig. 1. Regression of 26 cultivar or experimental population means for brown leafspot reaction (BLS) on year of release or synthesis (Y). Each point is a mean over three replicates and 3 yr at Arlington, WI. The rating scale was: $0=$ no symptoms, ..., $10=$ leaves completely diseased.

its parent, Saratoga (2.6 vs. 4.6; $P<0.01)$. All meadow and intermediate climatype entries had low brown leafspot resistance, with mean scores of 4.1 to 5.0, suggesting that there has been less selection pressure for resistance in meadow climatype germplasm compared to steppe climatype germplasm.

Improvements in brown leafspot resistance are considered beneficial for protecting both forage yield and IVDMD (Gross et al., 1975). Although there is no documentation of a direct effect of brown leafspot reaction on forage yield per se, negative rank correlation coefficients between brown leafspot reaction and first-harvest forage yield $(r=-0.43 ; P<0.05)$ or regrowth forage yield $(r=-0.33 ; P<0.10)$ at Wisconsin suggested a possible yield increase associated with resistance in some entries. Similarly, Gross et al. (1975) estimated that an 8.3 unit decrease in percentage diseased leaf area would increase IVDMD by $10 \mathrm{~g} \mathrm{~kg}^{-1}$.

\section{Forage Yield}

The efficiency of nearest neighbor analysis for total annual forage yield ranged from 94 to $163 \%$ with a mean of $116 \%$. Locations were highly variable in their mean relative efficiency: Illinois (128\%), Kansas (135\%), Nebraska (97\%), New York (102\%), North Dakota (107\%), West Virginia (122\%), and Wisconsin $(121 \%)$. Adjusted entry means were significantly different $(P<0.01$ for all locations, except Illinois which had $P<0.05)$. Entry $\times$ year interaction was significant $(P<$ 0.01) only for North Dakota and West Virginia, but consisted mainly of small changes in magnitude and rank value for entries of intermediate mean yield. Therefore all additional analyses were based on means over years.

There was a wide range in mean forage yield among entries at all locations, with the range exceeding the $\operatorname{LSD}(0.05)$ by 2 to 4.5 times, depending on location (Table 3). Mean yields at Illinois, Kansas, Nebraska, North Dakota, and Wisconsin were positively corre- 
Table 3. Means and significance levels for several comparisons of total annual forage yield related to the introduction and selection of smooth bromegrass in North America.

\begin{tabular}{|c|c|c|c|c|c|c|c|c|}
\hline \multirow[b]{2}{*}{ Statistic-Group-Contrast $\dagger$} & \multicolumn{7}{|c|}{ Location } & \multirow[b]{2}{*}{ Mean } \\
\hline & IL & $\mathbf{K S}$ & NE & NY & ND & WV & WI & \\
\hline \multirow{5}{*}{$\begin{array}{l}\text { Mean } \\
\text { High mean } \\
\text { Low mean } \\
\text { LSD }(0.05)\end{array}$} & \multicolumn{7}{|c|}{$\mathrm{Mg} \mathrm{ha}^{-1}$} & \\
\hline & 7.22 & $\mathbf{3 . 3 3}$ & 6.19 & 5.43 & 4.37 & 11.62 & 8.09 & \\
\hline & 8.54 & 4.06 & 6.99 & 6.33 & 5.29 & 12.77 & 8.87 & \\
\hline & 5.73 & 2.41 & 5.18 & 4.20 & 3.11 & 10.53 & 7.01 & \\
\hline & 1.44 & 0.50 & 0.60 & 1.16 & 0.49 & 1.12 & 0.76 & \\
\hline Introduced steppe type (IS) & ne & ne & 6.54 & 6.01 & 4.50 & 12.30 & 8.13 & 7.50 \\
\hline Selected steppe type (SS) & ne & ne & $7.29 *$ & 6.07 & $5.64 * *$ & 12.00 & $9.20 * *$ & $8.04 *$ \\
\hline Change per decade (b) & 0.088 & 0.088 & 0.005 & -0.125 & 0.142 & 0.080 & 0.028 & 0.044 \\
\hline SE(b) & 0.089 & 0.059 & 0.040 & 0.080 & 0.049 & 0.123 & 0.035 & $\mathbf{0 . 0 3 3}$ \\
\hline Selected for IVDMD & $8.83 * *$ & $3.55 * *$ & 6.20 & 5.15 & $4.57 * *$ & $12.03 * *$ & 8.26 & $6.94 *$ \\
\hline Not selected for IVDMD & 7.12 & 3.22 & 6.33 & $5.63^{*}$ & 4.39 & 11.41 & 8.17 & 6.61 \\
\hline $\begin{array}{l}\text { Nebraska entries (NE) } \\
\text { Wisconsin entries (WI) }\end{array}$ & 7.83 & $3.74 * *$ & 6.21 & $\begin{array}{l}4.85 \\
5.75 * *\end{array}$ & $4.75 * *$ & $12.25 *$ & 8.27 & 6.61 \\
\hline $\mathrm{NE} \times$ WI strain crosses & $8.47 * *$ & ne & $6.41 *$ & ne & $4.81 *$ & ne & $8.40 *$ & $7.02 *$ \\
\hline NE $\times$ WI midparent values & 7.58 & ne & 6.26 & ne & 4.63 & ne & 8.26 & 6.68 \\
\hline
\end{tabular}

*, ** IS vs. SS, IVDMD-selected vs. not selected, NE vs. WI, or strain crosses vs. midparents are significantly different from each other at $P<0.05$ or 0.01 . $\dagger$ IS = Lincoln, SS = mean of 21 steppe-type (southern) entries (Table 1); IVDMD selected vs. not selected identified in Table 1; NE = mean of LincolnHDMD-C3, Lincoln-HDMDYD-C3, NE BI 1, and NE BI 2; WI = mean of Alpha, Badger, and three WB10 populations; NE $\times$ WI strain crosses $=$ mean of WB19e and WB20e; NE $\times$ WI midparents = Lincoln-HDMD-C3, Lincoln-HDMDYD-C3, NE BI 1, NE BI 2, Alpha, and Badger.

+ Not estimable because of missing entries.

lated, with all but one of their 10 rank correlation coefficients between 0.30 and 0.66 (Table 4). Although the low value of some of these correlations suggested the presence of entry $\times$ location interaction, their relative uniformity suggests a reasonable agreement in ranking of entries among these five locations, despite the variation in BRM among these five locations (Table 2). New York and West Virginia showed almost no agreement with other locations, with the single exception of West Virginia vs. North Dakota $(r=0.52, P<0.05)$. Five of the 11 correlations involving these two locations were negative, suggesting that they tended to rank entries in a unique manner. The correlation coefficient between New York and West Virginia was $r=-0.04$, indicating no relationship between the two easternmost locations.

Selected steppe climatypes averaged $0.54 \mathrm{Mg} \mathrm{ha}^{-1}$ $(P<0.05)$ higher in forage yield than the introduced steppe germplasm that had no breeding history (Lincoln), despite lack of significance at two of the five locations. Since the release of Lincoln in 1942, most new cultivars have been developed by selection and breeding. The mean superiority of post-1942 cultivars to Lincoln was due to collective use of higher yielding germplasm in breeding programs, rather than gradual gains during the next $50 \mathrm{yr}$. Responses of forage yield to date-of-release, post-1942, were significant only when measured at North Dakota $\left(b=0.142 \pm 0.049 \mathrm{Mg} \mathrm{ha}^{-1}\right.$ decade $^{-1}$; Table 3 ). The mean response over locations was $b=0.044 \mathrm{Mg} \mathrm{ha}^{-1}$ decade $^{-1}\left(0.7 \%\right.$ decade $^{-1} ; P=$ 0.12 ), which is less than one-fifth of the response observed for many other forage crops (Veronesi, 1991). As another measure of progress from 1942 to the present, seven cultivars or experimental populations have been developed largely by selection within Lincoln, Saratoga, or Magna (Table 1). None of these cultivars had total annual forage yield significantly higher than their parent cultivar, either individually or collectively (data not shown).

Both the Nebraska and the Wisconsin breeding programs have emphasized selection for increased forage nutritive value, measured either by IVDMD or NDF concentration. Earlier reports suggest that recurrent selection for increased IVDMD has little or no effect on forage yield of smooth bromegrass (Carpenter and Casler, 1990; Ehlke et al., 1986). Data from this study confirm those previous conclusions, but also suggest that both IVDMD and forage yield can be simultaneously improved. Populations selected for IVDMD averaged $0.33 \mathrm{Mg} \mathrm{ha} \mathrm{ha}^{-1}(P<0.05)$ higher in forage yield than unselected populations (Table 3 ). Only at New York were unselected populations significantly higher in forage yield than IVDMD-selected populations.

Three cultivars form a direct line of descent, illustrating progressive increases in regrowth forage yield. York was selected from Rebound, which was selected from Saratoga, both for increased regrowth yield or more

Table 4. Rank correlation coefficients among seven locations of the smooth bromegrass test for total annual forage yield (above diagonal) or in vitro dry matter digestibility (below diagonal).

\begin{tabular}{|c|c|c|c|c|c|c|c|}
\hline \multirow[b]{2}{*}{ Location } & \multicolumn{7}{|c|}{ Location } \\
\hline & IL & KS & NE & NY & ND & WV & WI \\
\hline Illinois (IL) & & $0.46^{*}$ & 0.39 & -0.42 & 0.30 & -0.18 & 0.35 \\
\hline Kansas (KS) & 0.31 & & $0.66^{* * *}$ & -0.31 & $0.44 *$ & 0.34 & 0.08 \\
\hline Nebraska (NE) & 0.02 & $0.48 *$ & & 0.21 & $0.41 *$ & -0.05 & $0.44 *$ \\
\hline New York (NY) & 0.19 & 0.08 & 0.34 & & -0.41 & -0.04 & 0.18 \\
\hline North Dakota (ND) & 0.16 & 0.25 & $0.61 * *$ & 0.37 & & $0.52 *$ & $\mathbf{0 . 3 8} *$ \\
\hline West Virginia (WV) & 0.28 & -0.04 & 0.09 & $0.48^{*}$ & 0.38 & & 0.25 \\
\hline Wisconsin (WI) & $0.52 * *$ & 0.38 & 0.31 & 0.36 & $0.41 *$ & $0.59 *$ & \\
\hline
\end{tabular}

*, ** Correlation coefficient significantly different from zero at $P<0.05$ or 0.01 . Degrees of freedom range from 10 to 28. 
rapid recovery (Alderson and Sharp, 1994; Casler and Carlson, 1995). Averaged across the four locations at which regrowth was measured (NE, NY, WV, and WI), York and Rebound ranked \#1 and \#2 among all entries, respectively, in regrowth forage yield.

\section{Forage Quality}

Differences among entry means for IVDMD, NDF, and $\mathrm{N}$ concentration were significant for all locations, except Illinois (all three variables). There were no entry $\times$ year interactions for these three variables. Entry means differed by up to $67 \mathrm{~g} \mathrm{~kg}^{-1}$ in IVDMD (Table 5 ). All but one rank correlation coefficient between locations for IVDMD were positive (Table 4), indicating general concordance in ranking of entries. Furthermore, there was no pattern to the IVDMD correlation matrix, as was observed for the forage yield correlation matrix. Although these data still indicate the presence of some entry $\times$ location interactions, as indicated by some of the small correlations, they also support the general observation that IVDMD of smooth bromegrass is relatively insensitive to genotype $\times$ environment interaction (Buxton and Casler, 1993).

Mean IVDMD of steppe climatype germplasm (excluding Lincoln) was significantly lower than for Lincoln $\left(-15 \mathrm{~g} \mathrm{~kg}^{-1} ; P<0.01\right)$. This trend was observed at all five locations for which the comparison could be made, although it was significant at only three of the five locations. This observation is additional indirect evidence supporting the speculation of Carpenter and Casler (1990) and Vogel and Sleper (1994) that, historically, forage breeding and natural selection have tended to reduce the forage quality of temperate forage grass populations. This is likely due to long-term selection pressure for both natural and agricultural fitness traits, such as high forage and/or seed yield, lodging resistance, and increased concentrations of cell wall components that confer higher yield, lodging resistance, and perhaps resistance to herbivory.

Between 1942 and 1995, there was little evidence for any overall changes in IVDMD, with linear responses to release date highly variable among locations (Table 5). Linear responses to release date were significant for IVDMD only for West Virginia and Wisconsin, averaging $3.3 \mathrm{~g} \mathrm{~kg}^{-1} \mathrm{decade}^{-1}(0.5 \%$ of the mean per decade; $P<0.05)$. This mean response is only about one-fifth of that typically observed during recurrent selection for increased IVDMD, reflecting the fact that most cultivars do not represent improvements in forage nutritive value.

Two sets of contrasts gave evidence of recent improvements in forage nutritive value (Table 5). Two selections from Lincoln demonstrated evidence of increased IVDMD, albeit with very small changes that were not consistent among locations. In addition, the overall mean of all entries selected for increased IVDMD was $9 \mathrm{~g} \mathrm{~kg}^{-1}(P<0.01)$ higher than the overall mean of all entries that had not received such selection pressure. This effect was significant at all locations, except Illinois. Both this general response and the specific responses within Lincoln support previous observations that IVDMD can be readily improved in smooth bromegrass by recurrent selection (Carpenter and Casler, 1990). Wisconsin entries selected for increased IVDMD averaged $7 \mathrm{~g} \mathrm{~kg}^{-1}(P<0.01)$ higher than Nebraska entries selected for increased IVDMD, possibly due to the additional emphasis placed on concomitant selection for forage yield in the Nebraska system. The superiority of Lincoln-HDMD-C3 over Lincoln-HDMDYD-C3 for IVDMD also reflects lack of concomitant selection pressure for forage yield in Lincoln-HDMD-C3.

Two strain crosses between high-IVDMD germplasm from the Nebraska and Wisconsin programs (WB19e

Table 5. Means and significance levels for several comparisons of in vitro dry matter digestibility (IVDMD) related to the introduction and selection of smooth bromegrass in North America.

\begin{tabular}{|c|c|c|c|c|c|c|c|c|}
\hline \multirow[b]{2}{*}{ Statistic-Group-Contrast $\dagger$} & \multicolumn{7}{|c|}{ Location } & \multirow[b]{2}{*}{ Mean } \\
\hline & IL & KS & NE & NY & ND & WV & WI & \\
\hline & & & & & & & & \\
\hline Mean & 707 & 659 & 670 & 645 & 625 & 662 & 706 & \\
\hline High mean & 719 & 686 & 707 & 679 & 655 & 683 & 730 & \\
\hline Low mean & 694 & 630 & 640 & 618 & 591 & 645 & 689 & \\
\hline $\operatorname{LSD}(0.05)$ & 18 & 21 & 19 & 23 & 22 & 15 & 19 & \\
\hline Introduced steppe type (IS) & neł & ne & $671^{*}$ & $630 *$ & $643^{*}$ & 645 & 699 & $658 * *$ \\
\hline Selected steppe type (SS) & ne & ne & 655 & 617 & 614 & 638 & 692 & 643 \\
\hline Change per decade (b) & -0.2 & -0.5 & -3.4 & 2.8 & $-\mathbf{1 . 0}$ & 4.2 & 2.4 & 0.6 \\
\hline SE(b) & 1.3 & 3.1 & 2.7 & 3.2 & 2.6 & 2.2 & 1.2 & 1.7 \\
\hline Lincoln & ne & ne & 671 & 630 & 643 & 645 & 699 & 646 \\
\hline Lyon & ne & ne & 687 & 632 & 621 & 648 & 696 & 646 \\
\hline Lincoln HDMD C3 & ne & ne & 682 & $650 *$ & 638 & $659 *$ & 711 & $655^{*}$ \\
\hline Lincoln HDMDYD C3 & ne & ne & 683 & $655^{*}$ & 628 & $660 *$ & 699 & 652 \\
\hline Selected for IVDMD & 708 & $664^{*}$ & $682 * *$ & $660 * *$ & $635 * *$ & $666^{*}$ & $712 * *$ & $665^{* *}$ \\
\hline Not selected for IVDMD & 706 & 657 & 664 & 636 & 621 & 660 & 702 & 656 \\
\hline Nebraska entries (NE) & 707 & 667 & 681 & 657 & 631 & 658 & 703 & 662 \\
\hline Wisconsin entries (WI) & 714 & 658 & 684 & 666 & $639 *$ & $681 * *$ & $722 * *$ & $669 * *$ \\
\hline NE $\times$ WI strain crosses & 700 & ne & 675 & ne & 634 & ne & 706 & 679 \\
\hline NE $\times$ WI midparent values & 708 & ne & 676 & ne & 633 & ne & 707 & 681 \\
\hline
\end{tabular}

*, ** IS vs. SS, IVDMD-selected vs. not selected, NE vs. WI, or strain crosses vs. midparents are significantly different from each other, or population significantly different from Lincoln at $P<0.05$ or 0.01 .

$\dagger$ IS = Lincoln; SS = mean of 21 steppe-type (southern) entries (Table 1); IVDMD selected vs. not selected identified in Table 1; NE = mean of LincolnHDMD-C3, Lincoln-HDMDYD-C3, NE BI 1, and NE BI 2; WI = mean of Alpha, Badger, and three WB10 populations; NE $\times$ WI strain crosses = mean of WB19e and WB20e; NE $\times$ WI midparents = Lincoln-HDMD-C3, Lincoln-HDMDYD-C3, NE BI 1, NE BI 2, Alpha, and Badger.

$\uparrow$ Not estimable because of missing entries. 
Table 6. Means and significance levels for several comparisons of neutral detergent fiber (NDF) concentration related to the selection of smooth bromegrass in North America.

\begin{tabular}{|c|c|c|c|c|c|c|c|c|}
\hline \multirow[b]{2}{*}{ Statistic-Group-Contrast } & \multicolumn{7}{|c|}{ Location } & \multirow[b]{2}{*}{ Mean } \\
\hline & IL & KS & NE & NY & ND & WV & WI & \\
\hline & & & & & & & & \\
\hline Mean & 671 & 660 & 660 & 713 & 647 & 697 & 680 & \\
\hline High mean & 682 & 679 & 672 & 737 & 673 & 708 & 690 & \\
\hline Low mean & 660 & 642 & 642 & 682 & 626 & 680 & 669 & \\
\hline $\operatorname{LSD}(0.05)$ & 15 & 18 & 8 & 15 & 14 & 12 & 13 & \\
\hline Selected for IVDMD & 669 & 654 & 655 & 702 & 640 & 695 & 677 & 663 \\
\hline Not selected for IVDMD & 671 & $664 * *$ & $664 * *$ & $\mathbf{7 2 0} * *$ & 650** & 698 & $682^{*}$ & $671 * *$ \\
\hline Nebraska entries (NE) & 668 & 654 & $657^{*}$ & $706^{* * *}$ & $648^{*}$ & $700 * *$ & $681 * *$ & $667 * *$ \\
\hline Wisconsin entries (WI) & 667 & 653 & 651 & 695 & 634 & 686 & 671 & 658 \\
\hline
\end{tabular}

*, ** NE vs. WI, or IVDMD-selected vs. not selected are significantly different from each other at $\boldsymbol{P}<0.05$ or 0.01 .

and WB20e) had significant forage yield heterosis over their midparents $\left(0.34 \mathrm{Mg} \mathrm{ha}^{-1} ; P<0.05\right.$; Table 3). These strain crosses had no change in IVDMD relative to their midparents (Table 5), further suggesting that there is no inherent negative genetic correlation between IVDMD and forage yield. Smooth bromegrass hybrids, which have shown significant forage yield heterosis (Vogel et al., 1996), may be an excellent mechanism of improving forage yield without sacrificing accumulated gains in IVDMD, provided both parental strains have been selected for increased IVDMD.

Differences among entries for NDF tended to be smaller than observed for IVDMD, with a maximum range among entries of $55 \mathrm{~g} \mathrm{~kg}^{-1}$ (Table 6). In addition, fewer contrasts involving NDF were significant. Entries selected for increased IVDMD averaged an $8 \mathrm{~g} \mathrm{~kg}^{-1}$ $(P<0.01)$ reduction in NDF compared with those that had not been selected for IVDMD. This negative genetic correlation between NDF and IVDMD has also been observed within some recurrent selection populations (Carpenter and Casler, 1990; Ehlke et al., 1986). Furthermore, the higher IVDMD of the Wisconsin entries compared with the Nebraska entries was also associated with reduced NDF $\left(9 \mathrm{~g} \mathrm{~kg}^{-1} ; P<0.01\right)$. Both of these effects were significant at all but two locations, indicating a high degree of consistency and relatively little genotype $\times$ environment interaction.

There was only one contrast effect that indicated significant changes in $\mathrm{N}$ concentration associated with selection. Rebound and York (14.8 and $14.5 \mathrm{~g} \mathrm{~kg}^{-1}$, respectively) both had significantly $(P<0.01)$ higher $\mathrm{N}$ concentration than their parent cultivar Saratoga (12.8 $\left.\mathrm{g} \mathrm{kg}^{-1}\right)$.

\section{Cluster Analysis of Entries}

The cluster analysis of entry phenotypes showed considerable correspondence to known pedigree relationships (Fig. 2). Fifty percent of the sum of squares among entries was explained by five clusters of entries. Some of the close associations were of lines that are closely related to each other, eg. Lincoln and Lincoln-HDMDC3, WB19e and WB20e. However, most of the close associations were of lines that were phenotypically indistinguishable, but with diverse pedigrees, e.g., Rebound and Badger, 'Lancaster' and 'Manchar', and Saratoga and WB10-IN. This suggests that most germplasm pools of smooth bromegrass contain a wealth of genetic variability for a wide range of traits, allowing breeders to develop similar phenotypes from a wide range of apparently unrelated germplasm. Group I consisted of 13 entries, 11 of which derived from the Wisconsin or Nebraska programs, plus Rebound and Manchar. This group was of average mean phenotype and represented a typical range of phenotypic diversity for the entire group of entries (Table 7).

Group II contained only one entry, PL-BDR1, with the lowest mean brown leafspot reaction (Table 7). This appeared to be the single most unique entry in the test, simply because of its extremely low brown leafspot reaction. It had an average phenotype for all other variables.

Group III consisted of two Wisconsin experimental populations, WB10-IN and WB10-hD, and Saratoga. This group was characterized by high IVDMD and low NDF concentration, combined with the highest mean ground cover, high brown leafspot reaction, slightly below-average first-harvest forage yield, and average values of the other variables (Table 7). The inclusion of Saratoga in this group was something of a surprise, as it only ranked fourth for IVDMD and 7th for NDF concentration. However, Saratoga was nearly identical to the other two members of this group for forage yield, panicle height, ground cover, maturity, and brown leafspot reaction.

Group IV was an eclectic group of cultivars derived from unrelated breeding programs. They share an extremely tall average panicle height and a low mean IVDMD (Table 7). There are no indicators in the pedigrees of these cultivars to suggest that they should share these phenotypic traits, further indicating the large phenotypic diversity within numerous smooth bromegrass germplasm pools.

Group V was the most unique group, in that it represented both a clear phenotypic and genetic entity (Fig. 2 ). It showed the least phenotypic relationship to the other four groups, clustering with them at the last node in the dendrogram. These entries were characterized by extremely low first-harvest and regrowth forage yield and the highest mean brown leafspot reaction. This group included the three meadow (northern) climatypes plus two of the three intermediate climatypes (Signal and Magna). Morphological divergence between the meadow and steppe climatypes is well known and generally quite distinct (Vogel et al., 1996).

\section{Summary}

The experiment documented genetic gains made as a result of selection and breeding steppe-climatype 


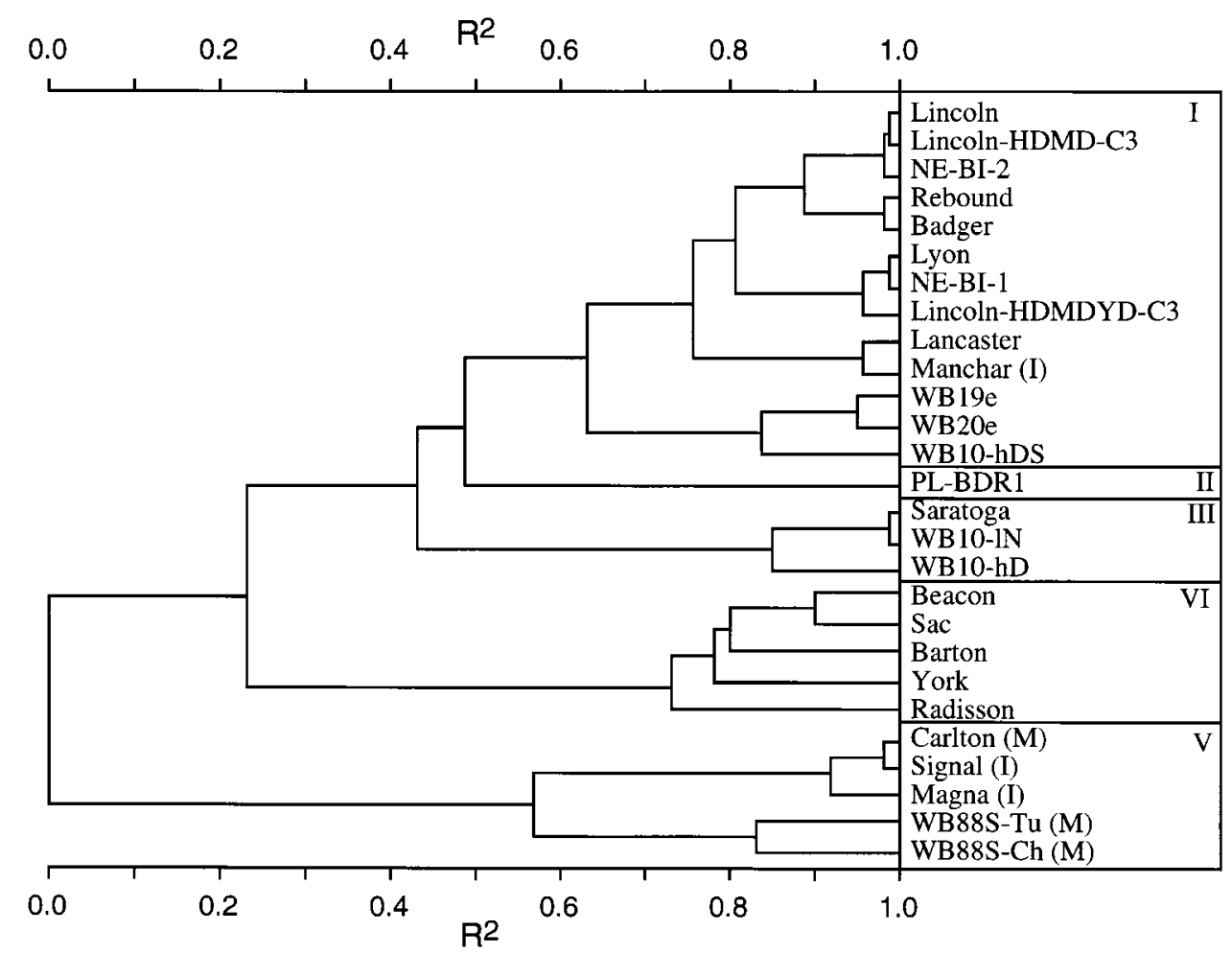

Fig. 2. Cluster dendrogram of 27 smooth bromegrass clutivars or populations evaluated at three locations (Nebraska, North Dakota, and Wisconsin) for nine variables (first-harvest and regrowth forage yield, panicle height, maturity, ground cover, brown leafspot reaction, IVDMD, $\mathrm{NDF}$, and $\mathbf{N}$ concentration). $\boldsymbol{R}^{2}=$ sum of squares among clusters $\div$ total sum of squares among entries. Letters inside parentheses indicate meadow (northern) climatypes (M) or intermediate climatypes (I); all others are steppe (southern) climatype.

smooth bromegrass in North America between 1942 and 1995. Progress was detectable for forage yield, brown leafspot resistance, IVDMD, and NDF concentration. Forage yield appears to have been improved over unselected introductions by approximately $0.7 \mathrm{Mg} \mathrm{ha}^{-1}$.

Progress from breeding smooth bromegrass has been slow compared with that observed in many crops. Unlike grain crops, progress has not been due to gradual increments during the past $50 \mathrm{yr}$, but rather is due to specific cultivars that have high yield potential, boosting the mean of the improved-cultivar group. Some of these cultivars have been on the market for many years. There are probably several reasons for this. First, the complex polyploid nature of smooth bromegrass conserves genetic variation for gradual release of new recombinants and transgressive segregants over many generations. This is advantageous over the long term, allowing slow, but sustained progress over many cycles of selection. Such slow rates of gain also suggest that considerable care must be exercised to avoid inbreeding in recurrent selection populations, either by using extremely large population sizes or by infusing new germplasm into the system on occasion.

Second, most of the emphasis during the past $20 \mathrm{yr}$

Table 7. Means and standard deviations for five clusters of smooth bromegrass entries which define $50 \%$ of the sum of squares among entries.

\begin{tabular}{|c|c|c|c|c|c|c|c|c|c|c|}
\hline \multirow[b]{3}{*}{ Group } & \multirow[b]{3}{*}{$n \dagger$} & \multicolumn{9}{|c|}{ Variable } \\
\hline & & \multicolumn{2}{|c|}{ Forage yield } & \multirow{2}{*}{$\begin{array}{c}\text { Panicle } \\
\text { height }\end{array}$} & \multirow{2}{*}{$\begin{array}{l}\text { Brown } \\
\text { leafspot } \\
\text { reaction }\end{array}$} & \multirow[b]{2}{*}{ Maturity } & \multirow{2}{*}{$\begin{array}{c}\text { Ground } \\
\text { cover }\end{array}$} & \multirow[b]{2}{*}{ IVDMD } & \multirow[b]{2}{*}{ NDF $\dot{\uparrow}$} & \multirow[b]{2}{*}{$\mathbf{N} \ddagger$} \\
\hline & & Cut 1 & Regrowth & & & & & & & \\
\hline & & \multicolumn{2}{|c|}{$-\mathrm{Mg} \mathrm{ha}^{-1}$} & \multirow[t]{2}{*}{ cm } & \multicolumn{2}{|c|}{ - score§ } & $\%$ & \multicolumn{3}{|c|}{$\longrightarrow \mathrm{g} \mathrm{kg}^{-1}$} \\
\hline & & & & & & Mean* & & & & \\
\hline I & 13 & $6.33 a$ & $2.61 \mathrm{a}$ & 99b & $3.7 \mathrm{~b}$ & $3.65 \mathrm{~b}$ & $90 \mathrm{~b}$ & $670 b$ & $661 b$ & 15.1bc \\
\hline II & 1 & $6.61 \mathrm{a}$ & $2.77 \mathrm{a}$ & $99 \mathrm{~b}$ & $1.2 \mathrm{~d}$ & $3.56 \mathrm{c}$ & $87 c$ & $665 \mathrm{bc}$ & 667ab & $14.6 \mathrm{c}$ \\
\hline III & 3 & $6.13 b$ & $2.54 a$ & $96 b$ & 4.1ab & $3.67 \mathrm{a}$ & 93a & $688 a$ & $649 \mathrm{c}$ & $15.6 \mathrm{~b}$ \\
\hline IV & 5 & $6.49 \mathrm{a}$ & $2.62 \mathrm{a}$ & $105 a$ & 3.1c & $3.69 \mathrm{a}$ & $87 c$ & $654 c$ & $668 a$ & $14.8 \mathrm{c}$ \\
\hline \multirow[t]{2}{*}{$\mathbf{V}$} & 5 & $5.82 \mathrm{c}$ & $2.33 b$ & $96 \mathrm{~b}$ & $4.5 \mathrm{a}$ & $3.65 \mathrm{~b}$ & $87 c$ & $661 c$ & $670 a$ & $16.2 \mathrm{a}$ \\
\hline & & \multicolumn{9}{|c|}{ Standard deviation } \\
\hline I & & 0.259 & 0.115 & 3.2 & 0.71 & 0.024 & 2.2 & 5.8 & 4.3 & 0.32 \\
\hline III & & $\mathbf{0 . 2 3 3}$ & 0.147 & 2.4 & 0.41 & 0.005 & 0.6 & 4.6 & 1.6 & 0.32 \\
\hline IV & & 0.260 & 0.147 & 1.8 & 0.57 & 0.024 & 4.1 & 10.6 & 7.2 & 0.44 \\
\hline V & & 0.422 & 0.186 & 4.2 & 0.41 & 0.042 & 3.2 & 4.9 & 2.6 & 0.19 \\
\hline
\end{tabular}

* Means followed by the same letter are not significantly different from each other when tested by LSD(0.05).

$\dagger \boldsymbol{n}=$ number of entries per group.

FVDMD = in vitro dry matter digestibility, NDF = neutral detergent fiber, $\mathbf{N}=$ nitrogen.

$\S$ See text for definition of scores. 
has been on forage quality traits and disease resistance, traits for which it is difficult and expensive to document their economic value. Third, smooth bromegrass has received very little attention from commercial breeding companies (Frey, 1996) which, for many species, contribute most cultivars and the greatest genetic gains to the marketplace. Fourth, the few smooth bromegrass breeders are generalists; they have large and diverse breeding programs that focus on numerous species, effectively reducing the rate of progress that could be achieved with a breeder's full effort. In 1994, there were 2.7 scientist years devoted to smooth bromegrass breeding in the USA public sector (Frey, 1996). Fifth, most smooth bromegrass public-sector breeding activity has emphasized germplasm, inheritance, and methodological research, rather than cultivar development. Genetic studies and germplasm research have provided a solid scientific basis for improving forage quality of smooth bromegrass.

\section{ACKNOWLEDGMENTS}

We thank Drs. Bruce Coulman, Robert Knowles, and Lowell Moser for their assistance in reviewing the manuscript and providing valuable comments and suggestions.

\section{REFERENCES}

Alderson, J., and W.C. Sharp. 1994. Grass varieties in the United States. USDA-SCS Agric. Handb. No. 170. Washington, DC.

Armstrong, K.C. 1985. Chromosome pairing failure in an intersectional amphiploid of Bromus-altissimus $\times$ B. arvensis. Can. J. Genet. Cytol. 27:705-709.

Armstrong, K.C. 1991. Chromosome evolution of Bromus. p. 363-377. In T. Tsuchiya and P.K. Gupta (ed.) Chromosome engineering in plants: Genetics, breeding, and evolution. Elsevier, Amsterdam.

Barnes, R.F, D.A. Miller, C.J. Nelson (ed.). 1995. Forages. Volume I. An introduction to grassland agriculture. Iowa State Univ. Press, Ames, IA.

Berg, C.C., R.T. Sherwood, and K.E. Zeiders. 1986. Recurrent phenotypic selection for resistance to brown leaf spot in smooth bromegrass. Crop Sci. 26:533-536.

Bremmer, J.M. 1996. Nitrogen-total. p. 1085-1121. In D.L. Sparks et al. (ed.) Methods of soil analysis. Part 3. Chemical methods. SSSA, Madison, WI

Brownie, C., D.T. Bowman, and J.W. Burton. 1993. Estimating spatial variation in analysis of data from yield trials: a comparison of methods. Agron. J. 85:1244-1253.

Buxton, D.R., and M.D. Casler. 1993. Environmental and genetic effects on cell wall composition and digestibility. p. 685-714. In H.G. Jung et al. (ed.) Forage cell wall structure and digestibility. ASA, CSSA, and SSSA, Madison, WI.

Buxton, D.R., K.P. Vogel, M.D. Casler, and K.J. Moore. 1995. Field survival of perennial forages divergently selected for digestibility. $\mathrm{p}$. 163. In Agronomy abstracts. ASA, CSSA, and SSSA, Madison, WI.

Carpenter, J.A., and M.D. Casler. 1990. Divergent phenotypic selection response in smooth bromegrass for forage yield and nutritive value. Crop Sci. 30:17-22.

Casler, M.D., and I.T. Carlson. 1995. Smooth bromegrass. p. 313-324. In R.F Barnes et al. (ed.) Forages. Volume I. An introduction to grassland agriculture. Iowa State Univ. Press, Ames, IA.

Casler, M.D., and K.P. Vogel. 1999. Accomplishments and impact from breeding for increased forage nutritional value. Crop Sci. 39:12-20.

Dunn, G.M., and M. Nasiruddin. 1971. Cytogenetics of a temperaturesensitive albino mutant in smooth bromegrass (Bromus inermis Leyss.). Crop Sci. 11:208-211.

Ehlke, N.J., M.D. Casler, P.N. Drolsom, and J.S. Shenk. 1986. Divergent selection for in vitro dry matter digestibility in smooth bromegrass. Crop Sci. 26:1123-1126.

Fehr, W.R. (ed.) 1984. Genetic contributions to yield gains of five major crop plants. CSSA Spec. Publ. No. 7. ASA, CSSA, and SSSA, Madison, WI.

Frey, K.J. 1996. National plant breeding study - I. Special Rep. 98. Iowa Agric. and Home Econ. Exp. Stn., Iowa State Univ., Ames, IA

Ghosh, A.N., and R.P. Knowles. 1964. Cytogenetic investigations of a chlorophyll mutant in bromegrass, Bromus inermis Leyss. Can. J. Genet. Cytol. 6:221-231.

Gross, D.F., C.J. Mankin, and J.G. Ross. 1975. Effect of diseases on in vitro digestibility of smooth bromegrass. Crop Sci. 15:273-275.

Knowles, R.P., and W.J. White. 1949. The performance of southern strains of bromegrass in western Canada. Sci. Agric. 29:437-450.

Milligan, G.W. 1980. An examination of the effect of six types of error perturbation on fifteen clustering algorithms. Psychometrica 45:325-342.

Moore, K.J., L.E. Moser, K.P. Vogel, S.S. Waller, B.E. Johnson, and J.F. Pedersen. 1991. Describing and quantifying growth stages of perennial forage grasses. Agron. J. 83:1073-1077.

Steel, R.G.D., J.H. Torrie, and D.A. Dickey. 1996. Principles and procedures of statistics: A biometrical approach. McGraw-Hill, New York.

Thomas, H.L., E.W. Hanson, and J.A. Jackobs. 1958. Varietal trials of smooth bromegrass in the North Central region. Minnesota Agric. Exp. Stn. Misc. Rep. 32.

Veronesi, F. 1991. Achievements in fodder crop breeding in mediterranean Europe. p. 25-30. In A.P.M. den Nijs and A. Elgersma (ed.) Fodder crops breeding: Achievements, novel strategies, and biotechnology. PUDOC, Wageningen, the Netherlands.

Vogel, K.P., K.J. Moore, and L.E. Moser. 1996. Bromegrasses. p. 535-567. In L.E. Moser et al. (ed.) Cool-season forage grasses. Agron. Monogr. 34. ASA, CSSA, and SSSA, Madison, WI.

Vogel, K.P., J.F. Pedersen, S.D. Masterson, and J.J. Toy. 1999. Evaluation of a filter bag system for NDF, ADF, and IVDMD forage analysis. Crop Sci. 39:276-279.

Vogel, K.P., and D.A. Sleper. 1994. Alteration of plants via genetics and plant breeding. p. 891-921. In G.C. Fahey et al. (ed.) Forage quality, evaluation, and utilization. ASA, CSSA, and SSSA, Madison, WI.

Watson, M.E., and R.A. Issac. 1990. Analytical instruments for soil and plant analysis. p. 691-740. In R.L. Westerman (ed.) Soil testing and plant analysis. 3rd ed. SSSA, Madison, WI. 